\title{
VIDÉKI TURISTÁK ALFÖLDI FÜRDŐKKEL VALÓ ELÉGEDETTSÉGE
}

\author{
Szabó Zoltán
}

\section{Összefoglalás}

\begin{abstract}
Magyarország jelentös hagyományokkal rendelkęik a fürdöturizmus fejlesztésében. A fejlesztések eredményeként jelentôs számú település rendelkezik minösitett fürdövel, melyek legnagyobb számban az. Alföldön találhatók. Az. utóbbi idöben a nemzetközi fürdöturizmus forgalma elött olyan akadályok voltak, melyek a belföldi turizmusnak kedveztek. A magyarokra is jellemző", hogy a z egészség felértékelödésével a fürdôturizmusban már nem elsösorban a városi emberek, hanem egyre jelentösebb számban a vidéki emberek vesznek részt. Ebben a kutatásban megviqusgálásra kerül az egyre növekvö s₹ámú, vidéken éló fürdöturisták elégedettsége a fürdók által nyújtott szolgáltatások minöségével. A kutatás eredményei arra bivják fel a figyelmet, hogy a vidéki turisták a fürdöszolgáltatások-minöségével elégedettek, de vannak olyan tényezók, amelyek. fejlesztése nem tür balasztást annake érdekében, hogy a fürdök a versenyképességüket megtarthassák.
\end{abstract}

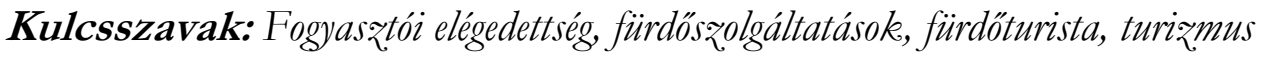
JEL: R19, Z32

\section{SATISFACTION OF RURAL TOURISTS WITH GREAT PLAIN'S SPAS}

\begin{abstract}
Absrtact
Hungary has a significant tradition in the development of spa tourism. As a result of the developments, a significant number of settlements have qualified baths, which are located in the largest number in the Great Plain. Recently, there are had been barriers to international spa tourism which favoured domestic tourism. It is also characteristic of Hungarians that with the appreciation of health, primarily no longer urban people involved in spa tourism, but increasingly in rural areas. This research examines the satisfaction of the increasing number of rural spa tourists with the quality of the services provided by the spas. The results of the research call attention to the fact that the rural tourists are satisfied with the quality of spa services, but there are factors whose development that must be done without delay in order to spas remain competitive.
\end{abstract}

Keywords: Consumer satisfaction, spa service, spa tourist, tourism JEL: R19, Z32 


\section{Bevezetés}

Világszerte tapasztalható, hogy a vidékfejlesztésre pozitív hatással van a turizmus, melyet a tudományos szakirodalom egyre gyakrabban tárgyal (Navarro et al. 2020; Sweeney, 1995). Közismert, hogy a turizmus fejlesztése hozzájárul a vidéki lakosság jólétének a növeléséhez és elősegíti a vidéki területek fejlődését (Miloradov - Eidlina, 2018).

A vidékfejlesztés jelentős tényezője a mezőgazdasági ágazat fejlődésének ösztönzése mellett a vidéki turizmus fenntartható fejlesztése (Bujdosó, 2016; Shejal, 2013). A fenntartható vidéki turizmus jellemzője, hogy figyelembe veszi a jelenlegi és jövőbeni társadalmi, gazdasági és környezeti hatásokat oly módon, hogy közben kielégíti a turisták és a helyi lakosok igényeit. A múlt századtól kezdve egyre fontosabbá vált a turisztikai ágazat számára a vidéki turizmus (Szabó - Hojcska, 2017), melynek fejlődését elősegítette az emberek újfajta életstílusa, a környezetvédelemmel kapcsolatos érzékenysége és az egészségmegőrzésre irányuló turisztikai magatartása (Bramwell et al. 2017; Botterill et al. 2013).

Európa gazdasági növekedése, valamint az európai emberek jóléte növekedésének köszönhetően és az egészségük megőrzésének igénye miatt az egészségturisztikai utazások száma megnövekedett (Hojcska, 2019; Ivancsóné - Printz-Markó 2018). Európa különböző országaiban az elmúlt évszázadok során az egészséggel kapcsolatos utazásokon résztvevők eltérő természeti erőforrásokra alapozott gyógykezeléseket vettek igénybe (Szabó - Hojcska, 2017).

Napjainkban az emberek az egészségesebb életmódra való törekvésük érdekében egyre több, az egészségipar által biztosított orvosi eljárásokat és természetes gyógytényezők felhasználásával gyógykezeléseket vesznek igénybe (Hojcska - Szabó, 2019). Magyarországon az egészségturizmus sajátos szegmense a fürdőturizmus (Printz-Markó - Albert-Tóth, 2018) amelyben a betegségek megelőzése és kezelése döntő többségében a fürdővel rendelkező településeken történik (1. ábra).

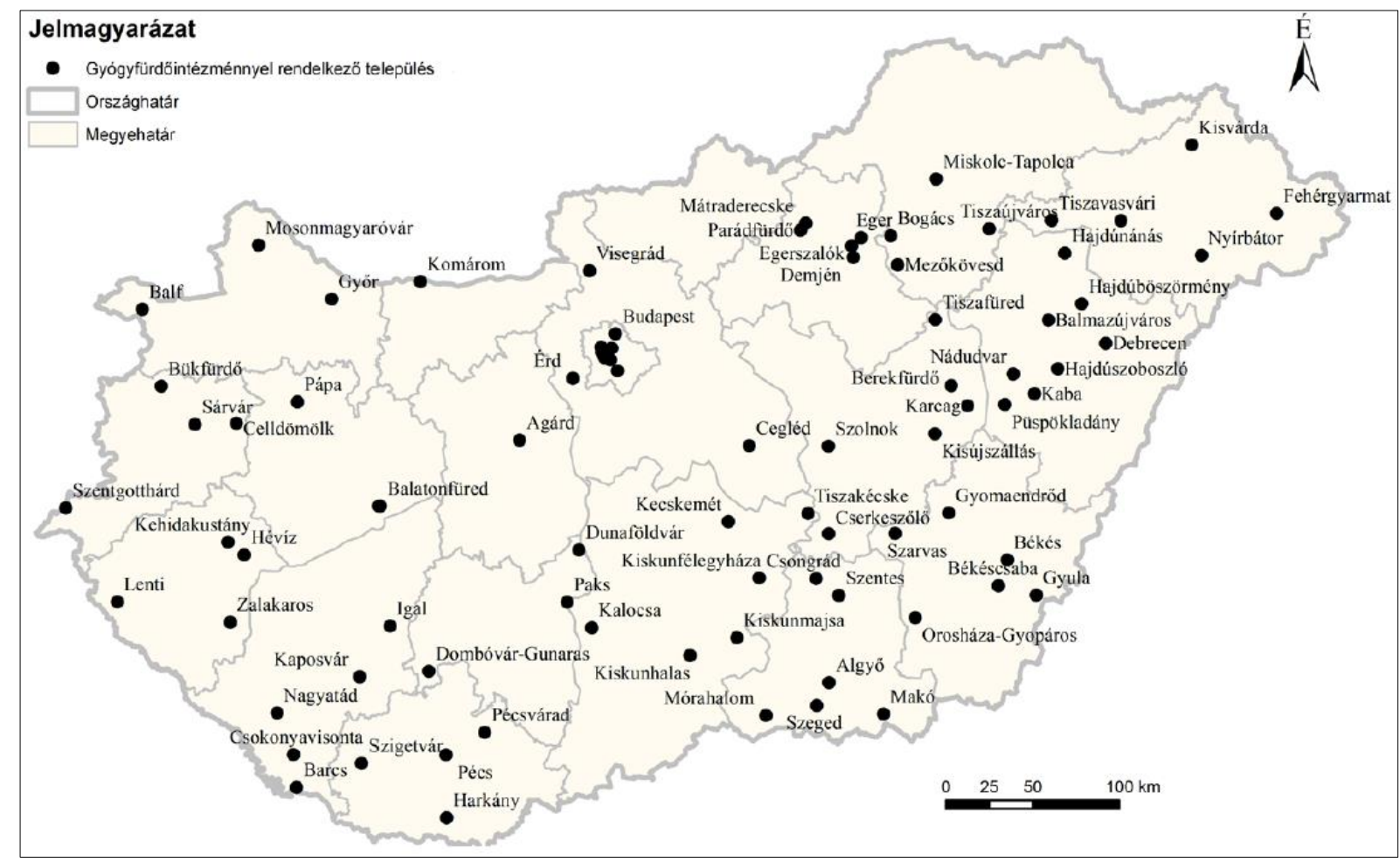

1. ábra. Magyarország fürdőkkel rendelkező települései Forrás: Lökee, 2019 
Hazánkban a természetes gyógytényezők közül leggyakrabban a gyógyvizet használják fel a fürdőkben és a hozzájuk kapcsolódó szolgáltatások nyújtása során (Szabó - Bujdosó 2020). Magyarországon a fürdők használatának nagy múltja és gazdag hagyománya van és napjainkban is jelentős szerepet játszanak a turisztikai forgalom lebonyolításában. Az elmúlt két évtized fürdőfejlesztéseinek köszönhetôen hazánkban a fürdőturizmus az egyik leggyorsabban növekvő turisztikai szegmenssé vált (Szabó, 2012).

A lehetőségeket kihasználva a hazai lakosság és azon belül a vidéken élők egyre nagyobb számban veszik igénybe a fürdők által nyújtott szolgáltatásokat (Szabó - Hojcska, 2020). A magyar fürdők többsége már felismerte, hogy a gazdasági sikerekhez és a piaci versenyelőnyhöz vezető út a vendégorientáción keresztül vezet, ezért egyre nagyobb figyelmet fordítanak a turisták elégedettségének a megismerésére (Printz-Markó, 2019). A turistának a szolgáltatásokkal való elégedettségét meghatározza a tapasztalata, vagyis az, hogy a turista legalább annyira legyen elégedett, mint amire számított. Tehát a turista megtapasztalja a szolgáltatást, és összehasonlítja a tapasztalatait az elvárásaival, melynek eredményeként megjelenik a vevői elégedettség vagy elégedetlenség. Ezért a turisztikai elégedettség a turista valós tapasztalatain és a nyújtott szolgáltatás minőségének megitélésén alapul (Hayati - Novitasari, 2017).

A szolgáltatások minősége két részből áll, a műszaki és a funkcionális minőségből, ahol a műszaki minőség arra utal, hogy a fogyasztó ténylegesen mit kap a nyújtott szolgáltatásból, míg a funkcionális minőség arra utal, hogy a fogyasztó hogyan fogadja a szolgáltatást. A szolgáltatás minőségének műszaki-technikai részét nem szabad elhanyagolni, de a funkcionális minőség a szolgáltatás minőségének értékelésében a legfontosabb tényező (Giese - Cote, 2000).

Kutatásom céljául tűztem ki, hogy feltárjam a vidéken élő, tág értelemben vett, középkorú magyar középosztálybeli fürdőturistáknak az Alföldön lévő fürdők szolgáltatás-minőségével való elégedettségét. A kutatás aktuális, mert a magyar fürdők a folyamatosan változó környezetben versenyképességük fenntartása, illetve növelése érdekében különböző piaci stratégiákat alkalmaznak. Ezért fontos megvizsgálni az egyre növekvő számú, vidéken élő fürdőturisták elégedettségét a fürdők által nyújtott szolgáltatások minőségével. A kapott eredmények alkalmasak lehetnek egyrészt a tudományos kutatóknak további kutatásaik megalapozására, másrészt a fürdôk menedzsmentje számára forrásaik hatékony felhasználása miatt a vidéki fürdőturisták elégedettségének növelése érdekében.

\section{Anyag és módszer}

A kutatás helyszínéül a fürdőkkel legsủrűbben ellátott Alföld három megyéjének egy-egy települését random módon választottam. A fürdőturisták megkérdezése Békés megyében, Szarvas városában, a Szarvasi Gyógyfürdőben, Csongrád-Csanád megyében, Szentes városában a Szentesi Üdülőközpont Fürdô Strand és Uszodában, valamint Jász-Nagykun-Szolnok megyében, Cserkeszőlő nagyközségben a Cserkeszőlő Fürdő és Gyógyászati Központban történt. A kitűzött kutatási célom elérése érdekében a kvantitatív kutatási módszerek közül a kérdőíves felmérést választottam, mert ez a leggyakrabban alkalmazott módszer a fogyasztói vélemények felmérésére (Lazaraton, 2005).

A vizsgálathoz a ServQual szolgáltatásminőség mérési modellből indultam ki, mely alkalmas a fürdőhöz kapcsolódó, a fürdőturisták által észlelt eltérő fürdőszolgáltatás minőségi jellemzők megismerésére, vagyis az észlelt minőség feltárására. A fürdőturisták által észlelt szolgáltatásminőség mérésére a ServQual módszer alapján a fürdők szolgáltatásaihoz kapcsolódóan 22 állitást tartal- 
mazó kérdőívet készítettem. Az állítások öt dimenzióba csoportosíthatók, ezek a „kézzelfoghatóság”, a „megbízhatóság”, a „fogékonyság”, a „,szavatolás/bizalom” és az „empátia” (Babakus Boller, 1992) (2. ábra).

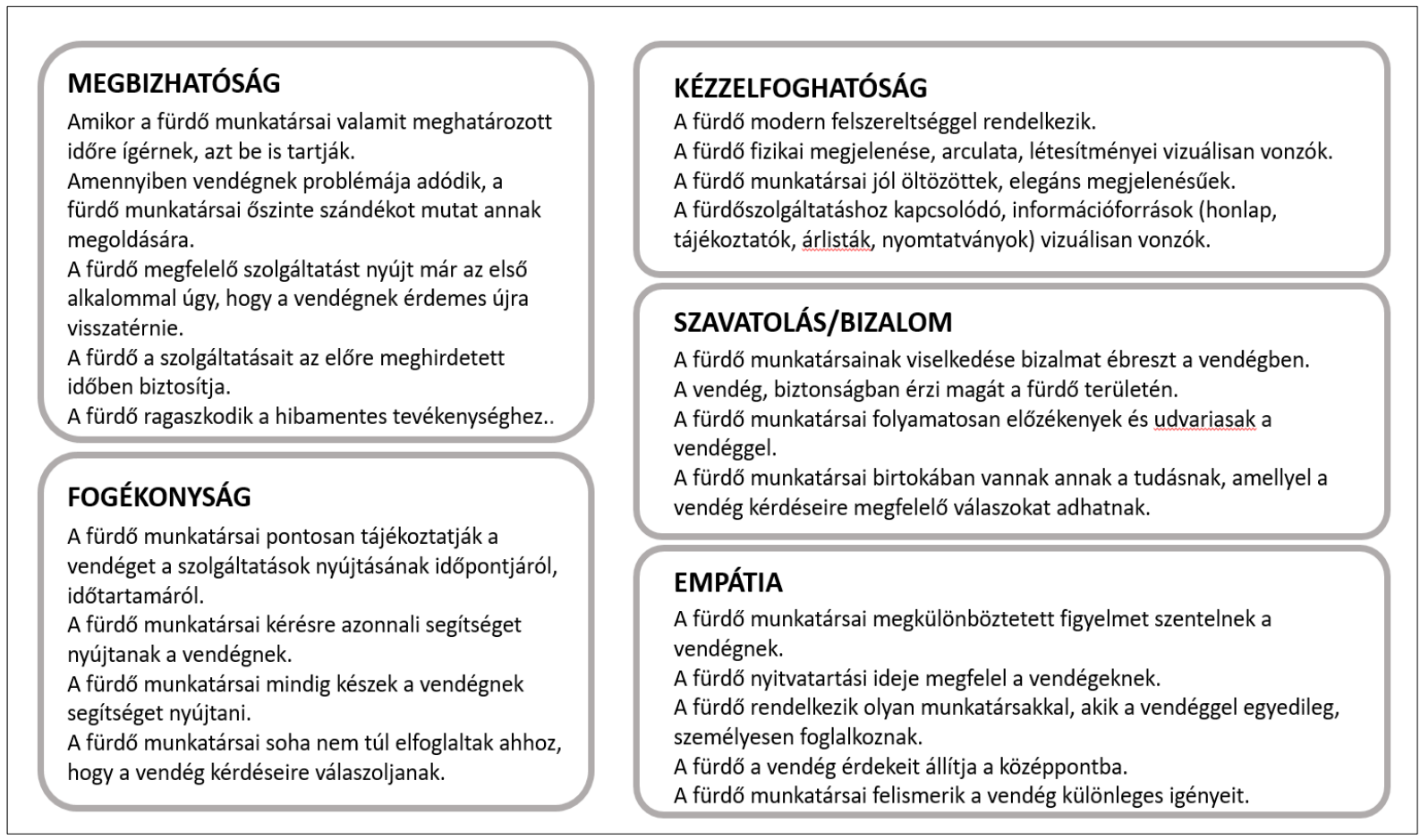

\section{2. ábra. A fürdők szolgáltatás-minőségének dimenziói}

Forrás: Finn,1991 alapján, saját szerkesztés

A kérdőívet a ServQual szolgáltatás-minőség elemzési módszer alapján a Likert-féle skálás, intervallumon mérhető kérdésfeltevésre készítettem el. Az egyetértési skálának az ötfokozatút választottam, mert a válaszadók ezt tudják a legjobban értelmezni úgy, mint az iskolai érdemjegyeket, az egyáltalán nem ért egyet-től (1), a teljesen egyetért-ig (5). A kérdőívben szereplő további hét kérdéssel a válaszadók szocio-demográfiai jellemzőit kívántam megismerni. Ennek érdekében rákérdeztem a válaszadók nemére, életkorára, gazdasági aktivitására, legmagasabb iskolai végzettségére, családi állapotára, családjának jövedelemszintjére, valamint a lakhelyére (Babbie, 2017; Gwatkin et al. 2000).

Az adatgyüjtés eszközének a hagyományos papír alapú kérdőívet alkalmaztam, melyet közvetítőkön keresztül juttattam el a válaszadókhoz. A megkérdezettek randomizált módszerrel kerültek kiválasztásra a három alföldi fürdőben. A válaszadókkal szemben támasztott követelményem az volt, hogy magyar állampolgár és nagykorú legyen. A kérdőíves megkérdezésre 2017. november 6. és 2018. január 15. közötti időszakban került sor a fürdőkben. Az adatgyüjtés során a szükséges számú minta elérése érdekében összesen 360 darab kérdőív, fürdőnként 120 darab került kiküldésre. A visszaküldött kérdőívekből 330 darab volt értékelhetően kitöltve, mely a mintaszám lett.

A kérdőíven szereplő válaszok számítógépes adatrögzítését követően, a kutatási célom elérése érdekében a begyüjtött adatok jellegzetességeit figyelembe véve a leíró statisztikai elemzést választottam. A statisztikai elemzéshez SPSS 23.0, Windows 10 programcsomagot használtam (Takács, 2016). A kérdőíveket értékelhetően kitöltő válaszadók szocio-demográfiai jellemzőit az 1. táblázat tartalmazza. 
1. táblázat. A válaszadók szocio-demográfiai jellemzői ( $\mathrm{N}=330)$

\begin{tabular}{|c|c|c|c|}
\hline \multicolumn{2}{|c|}{ Válaszadók jellemzői } & \multirow{2}{*}{$\begin{array}{r}\text { fö } \\
173\end{array}$} & \multirow{2}{*}{$\begin{array}{c}\text { megoszlás } \\
52,42 \%\end{array}$} \\
\hline & Nő & & \\
\hline 1 & Férfi & 157 & $47,58 \%$ \\
\hline \multirow{4}{*}{$\begin{array}{l}\text { Legmagasabb iskolai } \\
\text { végzettség }\end{array}$} & Általános iskola & 35 & $10,61 \%$ \\
\hline & Szakiskola & 77 & $23,33 \%$ \\
\hline & Érettségit adó középiskola & 133 & $40,30 \%$ \\
\hline & Főiskola, egyetem & 85 & $25,76 \%$ \\
\hline \multirow{3}{*}{ Gazdasági aktívitás } & Fizikai munkát végez & 153 & $38,18 \%$ \\
\hline & Szellemi munkát végez & 121 & $36,67 \%$ \\
\hline & Inaktív & 83 & $25,15 \%$ \\
\hline \multirow{2}{*}{ Családi állapot } & Egyedül él & 118 & $35,76 \%$ \\
\hline & Kapcsolatban él & 212 & $64,24 \%$ \\
\hline \multirow{4}{*}{ Jövedelemérzet } & $\begin{array}{l}\text { Legszükségesebbre elég jövedel- } \\
\text { műek }\end{array}$ & 11 & $3,33 \%$ \\
\hline & Szerény jövedelműek & 91 & $27,58 \%$ \\
\hline & Átlagos jövedeleműek & 191 & $57,88 \%$ \\
\hline & Átlag feletti jövedelműek & 37 & $11,21 \%$ \\
\hline \multirow{4}{*}{ Lakóhely } & Budapest & 53 & $16,06 \%$ \\
\hline & Megyei jogú város & 68 & $20,61 \%$ \\
\hline & Nem megyeszékhelyi város & 146 & $44,24 \%$ \\
\hline & Község & 63 & $19,09 \%$ \\
\hline
\end{tabular}

Forrás: Saját szerkesztés és sqámitás

A kérdőívet kitöltôk családi állapotuk szerint közel kétharmad részben párkapcsolatban, több mint egyharmad részben egyedül élnek, közel fele-fele arányban vannak a férfiak és a nôk. A válaszadók átlag életkora 47 év, legmagasabb iskolai végzettségüket tekintve egyharmad részüknek nincs, kértharmad részüknek van legalább érettségije. A megkérdezettek közül jövedelemérzetük alapján legtöbben azok vannak, akik átlagos jövedelemmel rendelkeznek, legkevesebben pedig azok, akiknek a jövedelme csak a legszükségesebbekre elég. A válaszadók gazdasági aktivitását tekintve negyed részük inaktív, háromnegyed részük aktív. A gazdaságilag aktív válaszadók között közel fele-fele arányban vannak a szellemi, valamint fizikai munkát végzők. A megkérdezettek közel kétharmad része vidéken él. 
Mivel a lakóhely szerint a budapesti és a megyei jogú városok nem, azonban a magyar kisvárosok és községek vidéki településeknek tekinthetők (Kovács - Farkas - Perger, 2015; Kovách, 2012), ezért a kutatás további részébe csak a községekben és a nem megyeszékhelyi városban élő válaszadók kerültek be. Így a vidéki válaszadók elemszáma az összes megkérdezett 63,33\%-a, vagyis 209 fő lett, akiknek a szocio-demográfiai jellemzőit a 3. ábra mutatja.

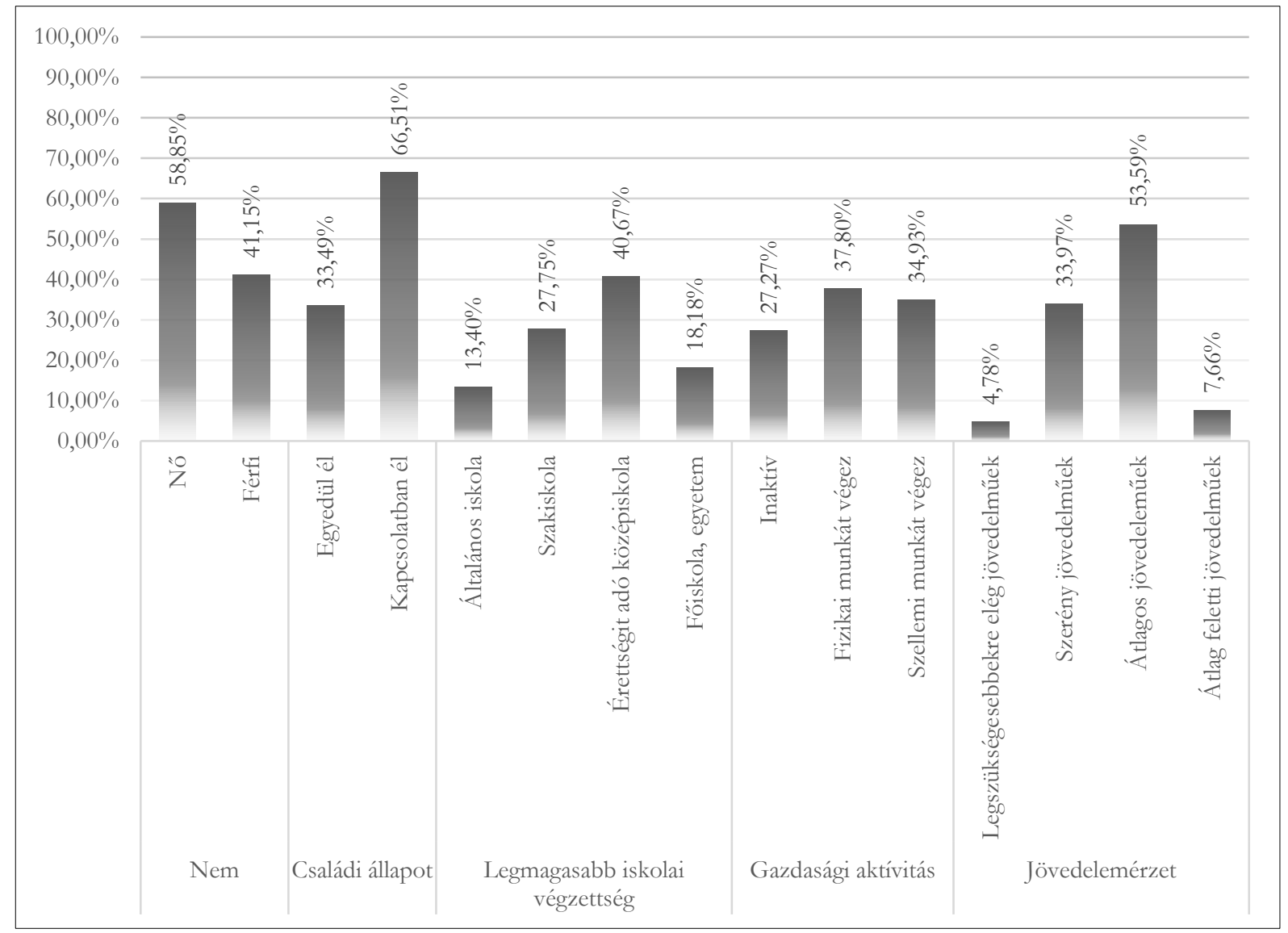

3. ábra. A vidéki válaszadók szocio-demográfiai jellemzői $(n=209)$

Forrás: Saját szerkesztés és számitás

A vidéki válaszadók szocio-demográfiai jellemzői jelentős mértékben hasonlítanak a teljes válaszadói kör jellemzőihez. A vidéken élő válaszadók átlag életkora 46,5 év. Legmagasabb iskolai végzettségüket tekintve legtöbben (40,67\%) érettségit adó középiskolába jártak, őket követik azok, akik szakiskolába (27,75\%) és felsőfokú oktatási intézménybe jártak (18,18\%), továbbá legkevesebben azok vannak, akiknek általános iskolába jártak (13,40\%). A vidéki megkérdezettek gazdasági aktivitását tekintve 27,27\% inaktív, az aktívak közül szellemi munkát 34,93\%, fizikai munkát $37,80 \%$ végez. A kérdőívet kitöltő vidéken élók családi állapotukat tekintve $66,51 \%$-a párkapcsolatban, 33,49\%-a egyedül él, 58,85\%-a nő, 41,15\%-a férfi. A vidéki válaszadók közül jövedelemérzetük alapján legtöbben azok vannak, akik átlagos jövedelemmel rendelkeznek (53,59\%), őket követik a szerény jövedelműek (33,97\%), majd azok, akik átlag feletti jövedelemmel rendelkeznek (7,66\%), legkevesebben pedig azok vannak, akiknek a jövedelme csak a legszükségesebbekre elég $(4,78 \%)$. 


\section{Eredmények}

\section{A vidéki turisták elégedettsége a fürdöszolgáltatások minöségével dimenziónként}

A vidéki turisták a három alföldi fürdő szolgáltatásainak minőségével jelentős mértékben, átlagosan 89,47\%-os mértékben voltak megelégedve. Az öt fürdőszolgáltatási minőségdimenzió egymáshoz képest kismértékủ eltéréseket mutat. A dimenziók közötti két szélsőérték között csupán 7,71\%pont eltérés van.

A megkérdezettek a fürdőszolgáltatások minőségével legkevésbé a „kézzelfoghatóság” dimenzióba tartozó fürdőszolgáltatásokkal, leginkább a „szavatolás/bizalom” dimenzióba tartozó fürdőszolgáltatásokkal voltak megelégedve (4. ábra).

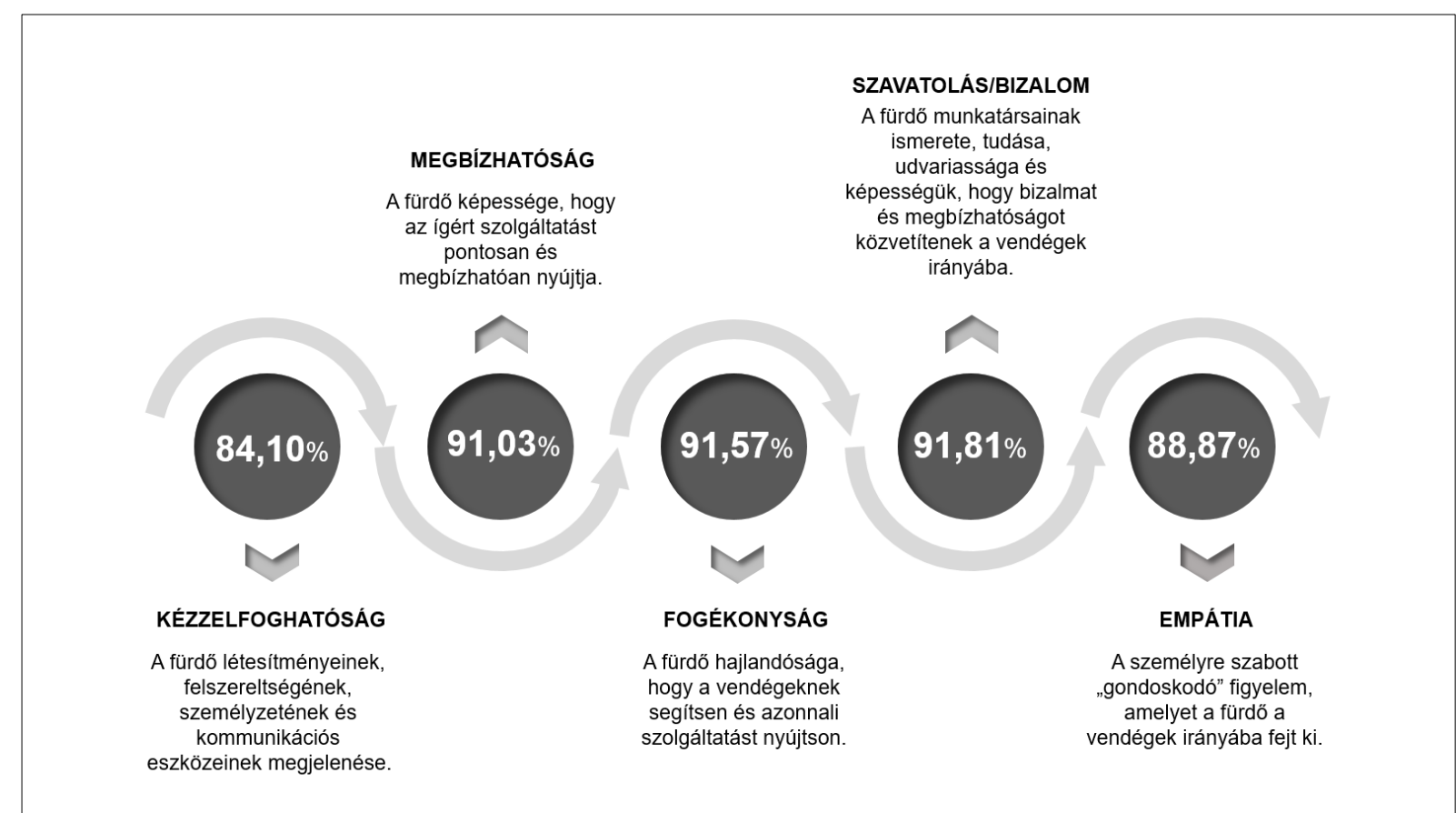

4. ábra. A vidéki turisták elégedettsége a fürdőszolgáltatások minőségével dimenziónként Forrás: Saját szerkesz̨és és sqámitás

A megkérdezettek legkisebb mértékben (84,10\%) a „kézzelfoghatóság” dimenzióval voltak megelégedve, vagyis a fürdôk létesítményeivel, felszereltségével, személyzetével, és kommunikációs eszközeinek megjelenései minőségével. A válaszadók legnagyobb mértékben (91,81\%) a „szavatolás/bizalom" dimenzióval voltak megelégedve, vagyis a fürdők munkatársai tudásának, ismeretének, udvariasságának és képességének a minőségével azáltal, hogy bizalmat és megbízhatóságot közvetítenek a fürdő munkatársai feléjük.

Az egyes fürdőszolgáltatási dimenziók átlagos értéktől (89,47\%) való eltérése alapján megállapítható, hogy a fürdőlátogató turisták két dimenziót az átlagos értéknél alacsonyabbra, három dimenziót pedig az átlagos értéknél magasabbra értékeltek. A fürdőszolgáltatási dimenziók átlagától 6,01\%-kal alacsonyabb a „kézzelfoghatóság” és 0,68\%-kal az „empátia”, magasabb 1,74\%-kal a „megbízhatóság”, 2,34\%-kal a „fogékonyság” és 3,31\%-kal a „szavatolás/bizalom” dimenziók. 


\section{A vidéki turisták fürdôszolgáltatásokkal kapcsolatos legalacsonyabb elégedettsége}

A vidéki turistáknak legalacsonyabb átlagos elégedettsége a fürdőszolgáltatás-dimenziók közül a „kézzelfoghatóság” dimenzióval volt, 4,77\%-ponttal elmaradva az „empátia” dimenziótól. A legalacsonyabb átlagos elégedettségi értéket mutató „kézzelfoghatóság” dimenzión belüli állításokkal való elégedettség egyiknél sem érte el a 90\%-os értéket, míg az „empátia” dimenzióban is csak egy állítás haladta meg a 90\%-ot (5. ábra).

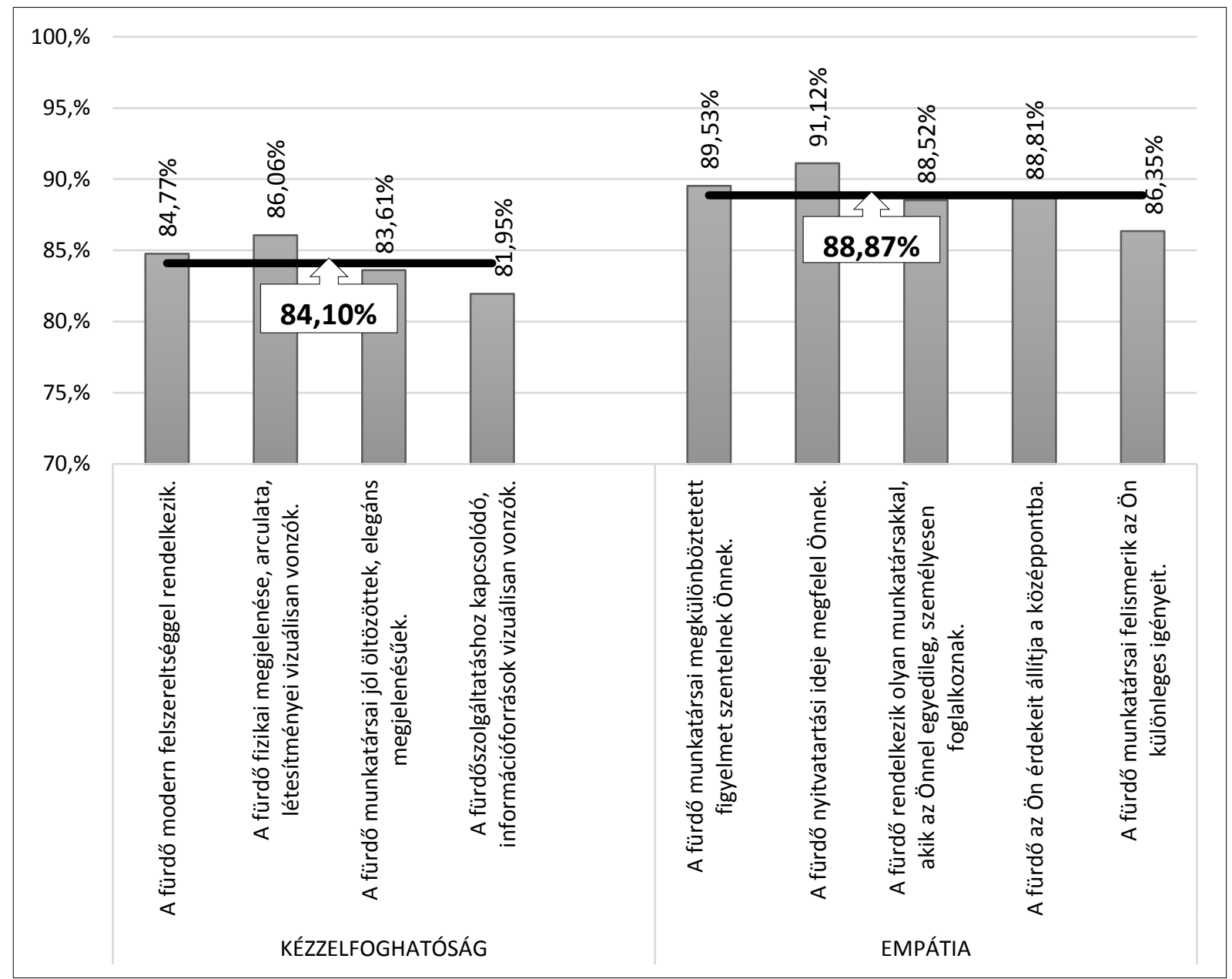

\section{5. ábra. A vidéki turisták legalacsonyabb elégedettsége} szolgáltatási csoportdimenziók szerint

Forrás: Saját sæerkesztés

A „kézzelfoghatóság” dimenzión belül átlag (84,10\%) alatti elégedettségi értékelést kapott a vidéki turisták véleménye alapján két állítás. Az átlagtól való elmaradás a „fürdőszolgáltatáshoz kapcsolódó információforrások vizuális megjelenése” állítás esetében 2,55\%, míg a „fürdő munkatársainak megjelenése, öltözete” állítás 0,58\%. Átlag feletti elégedettségi értékelést kapott a „kézzelfoghatóság” dimenzión belül szintén két állítás. A „fürdő modern felszereltségével való fogyasztói elégedettség” állítás az átlaghoz képest 0,75\%-kal, a „fürdő megjelenésével, arculatával, létesítményeivel való elégedettség” állítás az átlaghoz képest 2,34\%-kal magasabb.

Az „empátia” dimenzión belül átlag (88,87\%) alatti elégedettségi értékelést kapott a vidéki turistáktól három állítás. Az átlagtól való elmaradása a „fürdő munkatársai felismerik a vendégek igé- 
nyeit” állítás esetében 2,83\%, a „fürdő rendelkezik olyan munkatársakkal, akik a vendégekkel egyedileg, személyesen foglalkoznak” állításnál 0,39\% és a „fürdő a vendég érdekeit állítja a középpontba” állítás pedig $0,06 \%$. Átlag feletti elégedettségi értékelést kapott az „empátia” dimenzión belül a vidéki turisták véleménye alapján két állítás. A „fürdő nyitvatartási ideje megfelel a vendégeknek” állítással való fogyasztói elégedettség az átlaghoz képest 2,53\%-kal, a „fürdő munkatársai megkülönböztetett figyelmet szentelnek a vendégnek" $0,75 \%$-kal magasabb.

Összességében megállapítható, hogy a vidéki turisták a fürdők létesítményeinek, felszereltségének, személyzetének és kommunikációs eszközeinek megjelenésével voltak legkevésbé megelégedve, valamint azzal, hogy a fürdők személyre szabott „gondoskodó” figyelmet fordítanak a vendégek irányába.

\section{A vidéki turisták fürdőszolgáltatásokkal kapcsolatos legmagasabb elégedettsége}

A vidéki turistáknak legmagasabb átlagos elégedettsége a fürdőszolgáltatás-dimenziók közül a „szavatolás/bizalom” dimenzióval volt, 0,24\%-ponttal megelőzve a „fogékonyság” dimenziót és 0,78\%-ponttal megelőzve a „megbízhatóság” dimenziót. A legmagasabb átlagos elégedettségi értéket mutató két dimenzión („szavatolás/bizalom” és „fogékonyság”) belül mindegyik állítással való elégedettség meghaladta a 90\%-os értéket, míg a „megbízhatóság” dimenzióban is csupán csak egy állítás maradt alatta a 90\%-os elégedettségi értéknek (6. ábra).

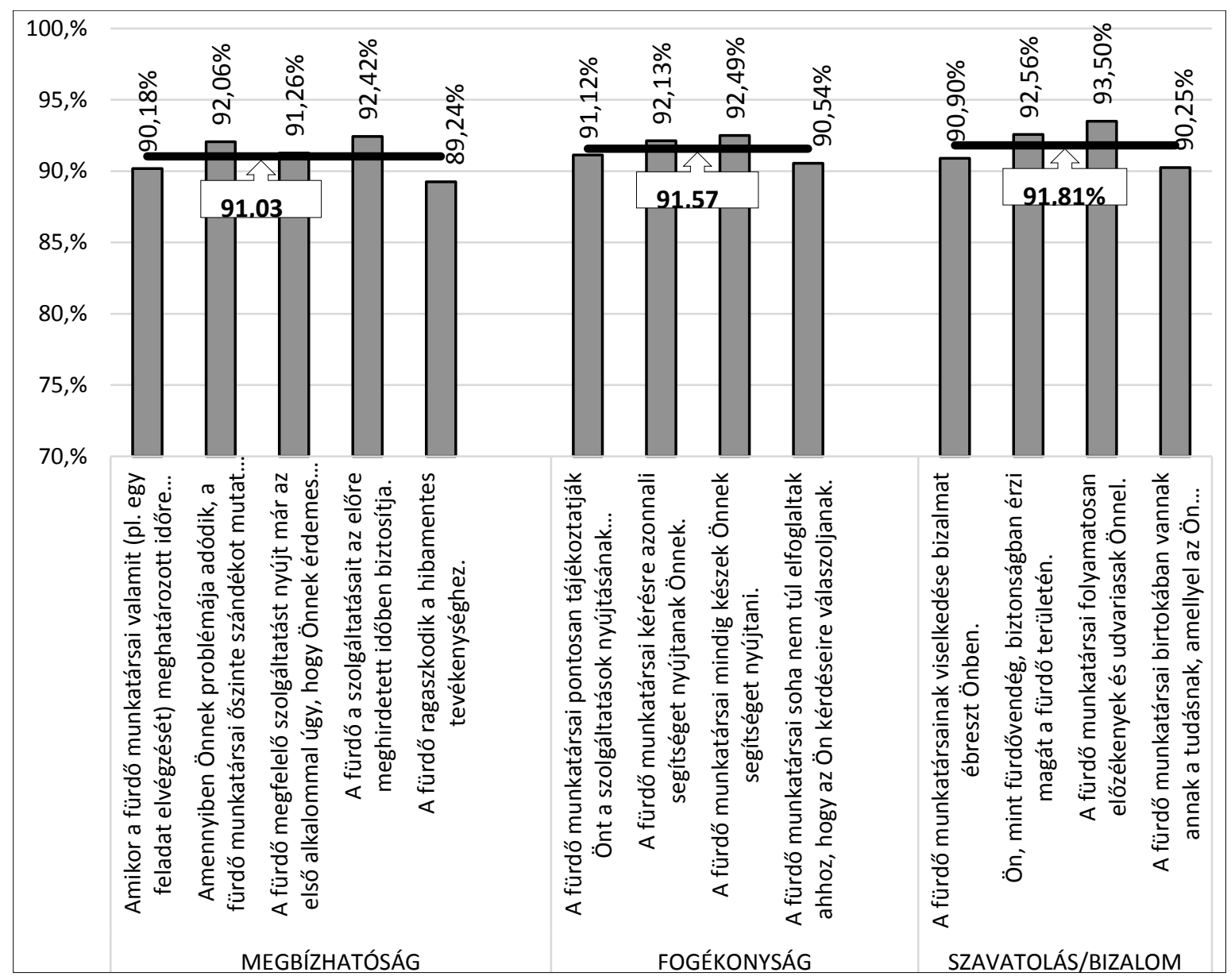

6. ábra. A vidéki turisták legmagasabb elégedettsége szolgáltatási csoportdimenziók szerint

Forrás: Saját szerkeszutés 
A „megbízhatóság” dimenzión belül átlag (91,03\%) feletti elégedettségi értékelést kapott a vidéki turisták véleménye alapján három állítás. A „fürdő a szolgáltatásait az előre meghirdetett időben biztosítja” állítás fogyasztói elégedettsége az átlaghoz képest 1,52\%-kal, ,amennyiben a vendégnek problémája adódik, a fürdő munkatársai őszinte szándékot mutat annak megoldására" 1,13\%-kal és a „fürdő megfelelő szolgáltatást nyújt már az első alkalommal úgy, hogy a vendégnek érdemes újra visszatérnie" 0,25\%-kal magasabb. Átlag alatti elégedettségi értékelést kapott két állítás. Az „amikor a fürdő munkatársai valamit meghatározott időre ígérnek, azt be is tartják” állítás fogyasztói elégedettsége az átlaghoz képest 0,49\%-kal, és a „fürdő ragaszkodik a hibamentes tevékenységhez $1,97 \%-k a l$ alacsonyabb.

A „fogékonyság” dimenzión belül átlag $(91,57 \%)$ feletti elégedettségi értékelést kapott a vidéki turisták véleménye alapján két állítás. A „fürdő munkatársai kérésre azonnali segítséget nyújtanak a vendégnek” állítás fogyasztói elégedettsége az átlaghoz képest $0,61 \%$-kal és a „fürdő munkatársai mindig készek a vendégnek segítséget nyújtani” 1,01\%-kal magasabb. Átlag alatti elégedettségi értékelést kapott két állítás. A „fürdő munkatársai pontosan tájékoztatják Önt a szolgáltatások nyújtásának időpontjáról, időtartamáról” állítás fogyasztói elégedettsége az átlaghoz képest 0,49\%-kal, a „fürdő munkatársai soha nem túl elfoglaltak ahhoz, hogy a vendég kérdéseire válaszoljanak” $1,12 \%$-kal alacsonyabb.

A „,szavatolás/bizalom” dimenzión belül átlag $(91,81 \%)$ feletti elégedettségi értékelést kapott a vidéki turisták véleménye alapján két állítás. A „,ürrdővendég, biztonságban érzi magát a fürdő területén” állítás fogyasztói elégedettsége az átlaghoz képest 0,83\%-kal, a „fürdő munkatársai folyamatosan előzékenyek és udvariasak a vendéggel" 1,85\%-kal magasabb. Átlag alatti elégedettségi értékelést kapott szintén két állítás. A „fürdő munkatársainak viselkedése bizalmat ébreszt a vendégben” állitás fogyasztói elégedettsége az átlaghoz képest 0,83\%-kal, a „fürdő munkatársai birtokában vannak annak a tudásnak, amellyel az vendég kérdéseire megfelelő válaszokat adhatnak" $1.85 \%$-kal alacsonyabb.

Összességében megállapítható, hogy a vidéki fürdőturisták legnagyobb mértékben a fürdők azon képességével voltak megelégedve, hogy az ígért szolgáltatást pontosan és megbízhatóan nyújtják, a fürdők hajlandóságával, hogy a vendégeknek segítsenek, és azonnali szolgáltatást nyújtsanak, valamint, hogy a fürdők munkatársainak ismerete, tudása, udvariassága és képessége bizalmat és megbízhatóságot közvetít a vendégek irányába.

\section{Következtetés, javaslatok}

A kitűzött kutatási célomat megvalósítottam, mert sikerült elérnem a vidéken élő válaszadók szocio-demográfiai jellemzői alapján a tág értelemben vett, középkorú magyar középosztályt. Továbbá sikerült feltárnom a vidéki turistáknak az alföldi fürdők szolgáltatás-minőségével való elégedettségét.

A kapott eredmények alapján, a vidéki turisták a fürdőszolgáltatások minőségével jelentősen, 89,47 százalékban meg voltak elégedve. A válaszadók legnagyobb mértékben a "szavatolás/bizalom” dimenzióba, legkisebb mértékben a „kézzelfoghatóság” dimenzióba tartozó fürdőszolgáltatásokkal voltak megelégedve. A vidéki turisták legkisebb mértékben voltak megelégedve a fürdők létesítményeinek, felszereltségének, személyzetének és kommunikációs eszközeinek megjelenésével, valamint azzal, hogy a fürdők személyre szabott „gondoskodó” figyelmet fordítanak a vendégek irányába. A vidéki turisták legnagyobb mértékben a fürdők azon képességével voltak megelégedve, hogy az ígért szolgáltatást pontosan és megbízhatóan nyúitja, a fürdők hajlandóságával, hogy 
a vendégeknek segítsen, és azonnali szolgáltatást nyújtson, valamint, hogy a fürdôk munkatársainak ismerete, tudása, udvariassága és képessége bizalmat és megbízhatóságot közvetít vendégek irányába.

A kapott eredmények alapján javasolt a vidéki turisták fürdőszolgáltatásokkal való elégedettségének növelése érdekében legelőször fejleszteni a fürdők létesítményeit, felszereltségét, személyzetének és kommunikációs eszközeinek megjelenését, valamint azt, hogy a fürdők a vendégek számára személyre szabott „gondoskodó” figyelmet fordítsanak. A kutatás eredményei arra hívják fel a figyelmet, hogy a vidéki turisták fürdőszolgáltatások-minőségével elégedettek, de vannak olyan tényezők, amelyek fejlesztése nem tủr halasztást annak érdekében, hogy a fürdők a versenyképességüket megtarthassák.

Anyagi támogatás: A közlemény megírása, illetve a kapcsolódó kutatómunka anyagi támogatásban nem részesült.

Érdekeltségek: A szerzőnek nincsen érdekeltsége.

\section{Hivatkozott források}

[1.] Babakus, E. - Boller, G. W. (1992): An empirical assessment of the SERVQUAL scale. Journal of Business research, 24(3), pp. 253-268. DOI: 10.1016/0148-2963(92)90022-4

[2.] Babbie, E. (2017): A társadalomtudományi kutatás gyakorlata. Budapest: Balassi Kiadó.

[3.] Botterill, D. - Pennings, G. - Mainil, T. (2013): Medical tourism and transnational health care. New York: Palgrave Macmillan.

[4.] Bramwell, B. - Higham, J. - Lane, B. - Miller, G. (2017): Twenty-five years of sustainable tourism and the Journal of Sustainable Tourism: looking back and moving forward. Journal of Sustainable Tourism, 25(1), pp. 1-9. DOI: 10.1080/09669582.2017.1251689

[5.] Bujdosó, Z. (2016): A turizmus és a területfejlesztés kapcsolatrendszere Magyarországon. In: Kókai, S (szerk.): A változó világ XXI. századi kibivásai: tanulmánykötet Prof. Dr. Hanusz. Árpád egyetemi tanár 70. sqületésnapja tiszteletére. Nyíregyháza: Nyíregyházi Egyetem Turizmus és Földrajztudományi Intézet, pp. 63-76.

[6.] Dávid, L. - Tóth, G. - Bujdosó, Z. - Herneczky, A.(2007): A turizmus és a regionális versenyképesség kapcsolatának mutatói a Mátravidék példáján keresztül. Észak-Magyarországi Stratégiai Füzetek, 4(1), 33-20.

[7.] Finn, D. W. - Lamb, C. W. Jr. (1991): An Evaluation of the Servqual Scales in a Retailing Setting. Advances in Consumer Research, 18(1), 483-490.

[8.] Giese, J. L. - Cote, J. A. (2000): Defining consumer satisfaction. Academy of marketing science review, 1(1), 1-22.

[9.] Gwatkin, D. R. - Rutstein, S. - Johnson, K. - Pande, R. - Wagstaff, A. (2000): Socio-economic differences in health, nutrition, and population. World Bank, 10(4), 272-282.

[10.] Hayati, N. - Novitasari, D. (2017): An Analysis of Tourism Service Quality Toward Customer Satisfaction (Study on Tourists in Indonesia Travel Destinations to Bali). International Journal of Marketing and Human Resource Management, 8(2), 9-20.

[11.] Hojcska, Á. E. - Szabó, Z. (2019): Fürdő-gyógykezelések igénybevételének felhasználói magatartás-vizsgálata gyógyszállodában. In: Kőszegi, I. R. (szerk.): III. Gazdálkodás és Menedæssment Tudományos Konferencia: Versenyképesség és innováció. Kecskemét: Neumann János Egyetem, Kertészeti és Vidékfejlesztési Kar, pp. 542-548. 
[12.] Hojcska, Á. E. (2019): Experiences of a professional study visit to spa towns in Germany. In: Ágnes, Erzsébet Hojcska (szerk.): Changing Spa Towns: 2nd Science Papers of the Spa Towns, Tata: Hungarian Spa Towns Association Society, pp. 208-227.

[13.] Ivancsóné Horváth, Zs. - Printz-Markó, E. (2018): Territorial differences between countries with regard to the wellness lifestyle of their youth. Forum Scientiae Oeconomia, 6(3), pp. 101-117. DOI: $10.23762 / \mathrm{FSO}$ vOL6 NO3 7

[14.] Kovách, I. (2012): A vidék ą ęredfordulón. Budapest: Argumentum-MTA szociológiai Kutatóintézet. Argumentum Kiadó.

[15.] Kovács, A. D. - Farkas, J. Z. - Perger, É. (2015): A vidék fogalma, lehatárolása és új tipológiai kísérlete. Tér és társadalom, 29(1), 11-34. DOI: 10.17649/TET.29.1.2674

[16.] Lazaraton, A. (2005): Quantitative research methods. In: Handbook of research in second language teaching and learning. New York: Routledge, pp. 209-224. DOI: 10.4324/9781410612700

[17.] Lőke, Zs. (2019): A minőség - elégedettség - lojalitás mérésének módszerei és tapasztalatai egy hazai gyógyfürdőben. Turizmus Bulletin, 19(2), 15-23.

[18.] Miloradov, K. - Eidlina, G. (2018): Analysis of tourism infrastructure development projects in the context of "Green economy". European Research Studies Journal, 21(4), 20-30. DOI: $10.35808 / \mathrm{ersj} / 1100$

[19.] Navarro, J. - Martínez, M - Jiménez, J. (2020): An approach to measuring sustainable tourism at the local level in Europe. Current Issues in Tourism, 23(4), pp. 423-437. DOI: $\underline{10.1080 / 13683500.2019 .1579174}$

[20.] Printz-Markó, E. - Albert, Tóth, A. (2018): Az egészségturizmus fogalomrendszerének modellezése kiválasztott nyugat-dunántúli fürdőtelepülések mintáján keresztül. Polgári Szemle: Gaz̧dasági és Társadalmi Folyóirat, 14(1-3), 205-220. DOI: 10.24307/psz.2018.0816

[21.] Printz-Markó, E. (2019): 'Changing bath towns' - in the spirit of sustainability: opportunities for service development along the water-based health tourism model based on the four ancient elements. In: Ágnes, Erzsébet Hojcska (szerk.): Changing Spa Towns: 2nd Science Papers of the Spa Towns, Tata: Hungarian Spa Towns Association Society, pp. 87-111.

[22.] Shejal, S. S. (2013): Agro-based Industries and Rural Development. International Journal of Scientific Research, 2(3), 98-99. DOI: 10.15373/22778179/mar2013/31

[23.] Sweeney, A. E. (2015): Rural tourism and sustainable rural development. Tourism Management, 16(4), 329. DOI: $10.1016 / 0261-5177(95) 90005-5$

[24.] Szabó, R. - Bujdosó, Z. (2020): A fürdő szerepe és jelentősége Bükkszék településfejlesztésében. In: Szabó, Z. - Bujdosó, Z. (szerk.): Fürdövárosok a turizmus fókuszában. Gyomaendrőd: Magyar Fürdővárosok Szövetsége, pp. 71-85.

[25.] Szabó, Z. (2012): A special opportunity of the use of natural resources: sustainable bathdevelopment through the eyes of mayors. In: Darabos, F. (szerk.): Kincseink védelmében: Fenntarthatóság és Körmyezettudatosság a turizmusban. Sopron: Nyugat-magyarországi Egyetem Kiadó, pp. 10-22.

[26.] Szabó, Z. - Hojcska, Á. E. (2017): Medical devices in the service of tourism in the XIX century. Zbornik Jankovic, 2(2), 61-75.

[27.] Szabó, Z. - Hojcska, Á. E. (2020): Rekreációs turisztikai fürdőszolgáltatások és azok igénybevételének összefüggés-vizsgálata egy SPA-szolgáltatónál. Recreation: A Közép-Kelet-Európai Rekeációs Társaság Tudományos Magazinja, 10(1), 36-39. DOI: 10.21486/recreation.2020.10.1.4

[28.] Takács, Sz. (2016): Bevezetés a matematikai statisztikába. Budapest: Antrész Kiadó. 


\section{Szerző}

Dr. Szabó Zoltán, PhD

ORCID 0000-0002-1088-8416

egyetemi docens

Magyar Agrár-és Élettudományi Egyetem Georgikon Campus

Szabo.Zoltan.dr@uni-mate.hu 